Przegląd Badań Edukacyjnych Educational Studies Review

ISSN 1895-4308

nr $32(1 / 2021)$, s. 75-98

Katarzyna Piwowar-Sulej

ORCID: https://orcid.org/0000-0002-4627-4344

Wroclaw University of Economics and Business, Poland;

e-mail: katarzyna.piwowar-sulej@ue.wroc.pl
ORYGINALNE ARTYKUtY BADAWCZE

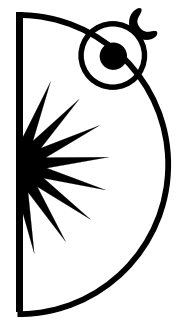

\title{
The Use of Gamification in Academic Teaching - Evidence from Polish State Universities
}

http://dx.doi.org/10.12775/PBE.2021.005

\begin{abstract}
The purpose of the article is to provide answers to the following research questions: How popular are digital games as the first step to gamification, comparing to other teaching methods used in such fields of study as economics, humanities and natural science in Poland? What is the practice of using gamification in academic teaching? The subject literature studies and empirical research carried out in the form of auditorium survey in the third quarter of 2019 across a sample of 200 students (50 people representing each field of study) were used in the article. In order to collect additional information, in-depth interviews with students (4 people representing each field of study) were carried out in the first quarter of 2020.

The problem of applying gamification in tertiary education is gaining importance, as evidenced by the growing number of scientific publications addressing this issue. The conducted empirical research shows that digital-game-based learning method is marginally used in academic teaching in Poland and, thus, it is hard to talk about gamification. The article also presents the research process limitations and directions of further research.
\end{abstract}

Keywords: educational games, computer games, gamification, tertiary education.

\section{Introduction}

In the times of rapid technological development and progressing globalization, the education of modern societies is gaining particular importance. For several 
years, both science and tertiary education in Poland have been subject to a profound reconstruction. The number of students increased in 2003-2012, but then in 2013-2018 decreased (Eurostat, 2020a) because of demographic reasons and new rules for student limits established by the Ministry of Science and Higher Education. The structure and conditions of universities' functioning have been changing. There are three levels of tertiary education, i.e. first, second and third cycle studies. The second cycle is completed by defending a master's thesis and the third one - doctoral dissertation. Private education expanded alongside state schools. On the one hand, they cooperate, whereas, on the other, a direct rivalry with foreign universities is noticeable. While competing on the increasingly difficult market of academic education, universities recruit students highlighting good education conditions and modern curricula in their offer.

The aforementioned transformations go along with the changes in students' expectations. In Poland student youth represent adults who usually start their university education at the age of 19 , sometimes later and graduate, most often, at the age of 24. A common phenomenon is extending the period of study, which can be continued even at the age of 30 , especially when a person decides to take up the third cycle of education. According to the research conducted by Stańczyk, only $1 / 7$ of the respondents approach university studies in the categories of autotelic values. For others it presents an instrumental value (Stańczyk, 2007).

Universities are dominated by the representatives of Millennials divided into generation $\mathrm{Z}$ (WWW, Net) and the earlier one - Y. According to the results of Junco and Mastrodicas (2007) studies, people born in 1982 (generation Z) use technology to a greater extent than the representatives of older generations (97\% have a computer, $94 \%$ a mobile phone and $76 \%$ use instant messengers). The research results presented in Statista database show that in Poland industry revenue from publishing computer games increased from 50 million USD in 2011 to more than 200 million USD in 2019 (Huhn, 2019). The share of Internet users playing video games in Poland increased from $60 \%$ in 2014 to $76 \%$ in 2019 (Szuba, 2019a). At the same time, Eurostat research results show that Poles rate their digital skills lower than the average for all EU countries (40\% of Poles admit having them, whereas the EU average is 54\%) (Eurostat, 2020b).

Young people feel like living in a "global village" as a result of unlimited access to the Internet. Time spent in front of the computer is devoted to learning, socializing, shopping and entertainment in a broad sense. At this point it is worth highlighting that playing computer games can have educational value and a device which is definitely most frequently used for educational reason is neither a smartphone nor tablet but a computer (Szuba, 2019b). 
The first computer games were developed in the 1940s (Wolf, 2012). The games created several decades ago and those of today have one thing in common: it is believed that the individuals playing computer games show stubbornness, determination and high commitment. It was found that the player's enthusiasm can be transferred into the real world and used in the process of solving actual problems - both in education and at work. In this way gamification was created - referred to as a new trend in management and marketing (Staszel, 2014). It uses game mechanics to modify people's behaviour - in the analysed case - students' behaviour.

Having the above in mind, the purpose of the study was defined, i.e. providing answers to the following research questions:

1. How popular are digital games as the first step to gamification, comparing to other teaching methods in such fields of study as economics, humanities and natural science in Poland?

2. What is the practice of using gamification in academic teaching?

The research process was based on both literature and empirical studies. Bibliometric analysis of the publications addressing tertiary education was based on the Scopus database. VosViewer software was also used to illustrate certain research trends. To accomplish the purpose of the article, empirical research methods such as auditorium survey and in-depth interview were used.

The first part of the study ("Literature Background") addresses the essence of games and gamification - in general terms and in relation to academic teaching. The second part covers the research methodology. The third part presents the results of empirical research and their discussion. The final part of the article - apart from the summary - reveals the research process limitations as well as the implications for science.

\section{Literature background. From games to gamification}

In 1938, a Dutch historian Huizing defined game as a voluntary activity considered as a deliberate and "less serious" separation from the "ordinary" world, while absorbing the player in an intense and complete way. This activity is not connected with any material benefit, thus making any profits from playing it impossible (Tkaczyk, 2012). In turn, the traditional definition of an educational game, according to Abt, describes a game as an activity between two or more independent decision-makers striving to achieve their goals in a limited context (the context takes the form of, e.g., the plot, props and rules of the game) (Abt, 
1970). A game can also be referred to as a form of entertainment (Klabbers, 2006). Finally, the term "serious game" is used in the subject literature. The word "serious" allows distinguishing between the typically entertaining games and the ones intended primarily to educate (Balcerak \& Woźniak, 2016).

Games have been used for educational purposes for a long time. In the course of playing the ancient game of chess, the medieval nobility learned war strategies. During the American Civil War, the volunteers from Rhode Island played the American Kriegsspiel, which was created in 1812 to train Prussian war officers (Institute of Play, 2014). The first games required simple props. Today, there are many types of games specified using such criteria as, e.g., teaching aids (card game, board game, computer game), knowledge level of the participants (beginner or advanced), focus on individual work vs. teamwork.

In general, the method of gaming inherently involves applying the rules of rational behaviour in conflict situations, i.e. the ones in which the result of an individual activity is influenced not only by their behaviour, but also by the actions of other individuals, with all of them presenting more or less conflicting interests. Frequently, games refer to the principles of social interdependence, result in a conflict between self-interest and that of the other party (the so-called prisoner's dilemma) or the entire group. The set of players (participants in conflict), the sets of their strategies and the set of all allowable situations and the related winnings constitute the elements determining the game. Game theory is investigating the rules for achieving optimal situations during the game, also referred to as equilibrium situations, and it is used to make decisions in economic systems in the conditions of uncertainty to minimize the losses incurred by the decision maker (Uniwersytet.pl, 2019). The effect of the game is similar every time: the more knowledge acquired by the participant and the skills trained while playing the game, or if the action strategy promoted by the game was used, the more is gained in the course of the game.

The research on adult learning indicates that the majority of such individuals acquire knowledge based on a specific experience or living through something that makes them reflect on it and, thus, acts as an incentive for taking up action (Kolb, 1984). The experience of positive feelings (e.g. satisfaction from the team's victory), but also negative emotions (e.g. frustration caused by the difficulties arising during the game or a failure) result in, respectively: the desire to repeat behaviours leading to success and avoiding the ones causing failure (Dias, 2017). A well-designed game frequently stands for a simulation or a metaphor of reality, which is later easily recalled by the participants in the situation of a specific problem and triggers a chain of behaviours that facilitate taking 
advantage of the acquired skills. The pleasure of participating in a game is associated with an opportunity to test oneself in new situations, overcome new challenges, remain a part of the players' community and finally of the entire competition. Some psychologists believe that competition is a natural tendency and aspiration followed by a human being. However, there is no clear evidence whether people prefer to compete or to cooperate (Doliński, 1998). Against this background, the research results carried out by Chorab (2014) are interesting. Polish undergraduates are aware that they remain competitors for their fellow students on the labour market. Competition begins still in college, when students support each other while learning, taking exams and struggling to earn scholarships, the latter even tough not impressive, to some extent, motivate to compete. It is worth noting that gamification not only allows independent learning, but also knowledge sharing (Reiners \& Wood, 2014). Therefore, a strand of cooperation, mutual education of the participants, searching for a solution by asking questions another student, the game participant, can be introduced into a game.

The term "gamification" was used for the first time in 2002 by a programmer N. Pelling (Misztal, 2015). Gamification uses game mechanics to modify people's behaviour - in the analysed case students and future employees. Gamification is also referred to as "the combination of psychology and technology" (Duggan \& Shoup, 2013). Some authors define gamification as solely an idea of integrating structure of the games into education (Hamari et al., 2014). However, gamification is a broader concept than the previously discussed educational games approached as a method possible to use by a teacher in a classroom. Gamification is a solution that extends beyond university premises. Individual tasks can be based on work (including learning) in the real world, in traditional conditions. Just Press Play system can serve as an example, as it combines what students do during and outside traditional classes with various tasks, merit badges and other elements used in games (Decker \& Lawley, 2013).

As indicated earlier, gamification goes beyond the university classroom. It is a continuous process characterised by a longer time perspective. Huotari and Hamari (2017) distinguished following aspects of gamification: affordances, psychological mediators, goals, and the context. Implementing gamification requires focusing on three principles - i.e. mechanics, dynamics and emotions (Robson et al., 2015) - and providing appropriate conditions. They cover as follows (McGonigal, 2011):

1. clear definition of the goals and rules of winning,

2. the same rules for all players, 
3. twists and turns of action, adventures, challenges,

4. voluntary participation,

5. in-game communication system.

In addition, the rules of winning should be based on scoring, which translates into collecting points by students for completing individual tasks. To increase the game attractiveness, points or grades can be called using original names, neologisms based on the university profile or the studied course, etc. Students can also be awarded badges. Participation in the game can be either individual or a team one, i.e. points can be collected either by individuals or teams (administrative groups). According to the idea of gamification, providing feedback on the results should take place in real time (Zichermann \& Cunningham, 2011), which requires IT systems that allow recording activities, assigning tasks, generating rankings and providing an ongoing feedback. That is why digital games, which present scores in a real time, can be the first step to gamification (Bellotti et al., 2013; Brigham, 2015). It is wort noting that the systematic literature review carried out by Wiggins (2016) revealed that several authors use gamification and game-based learning interchangeably.

\section{Gamification in tertiary education as the subject of scientific discussion}

The problem of gamification in terms of academic teaching is gaining importance. It is confirmed by the growing number of publications. After entering, on March 10, 2020, the following query in the Scopus database: TITLE-ABS-KEY ("gamification" AND ("tertiary education" OR "higher education" OR "universities" OR "academic teaching")) 900 documents were retrieved. Figure 1 presents the number of studies indexed in the above-mentioned database over the years. The first studies were developed in 2011 .

As the information presented in Figure 2 shows, the largest number of publications addressing the issue of gamification in academic teaching was created in the USA. When it comes to the European countries, this problem is most often discussed by the researchers from Spain, the United Kingdom and Germany. 


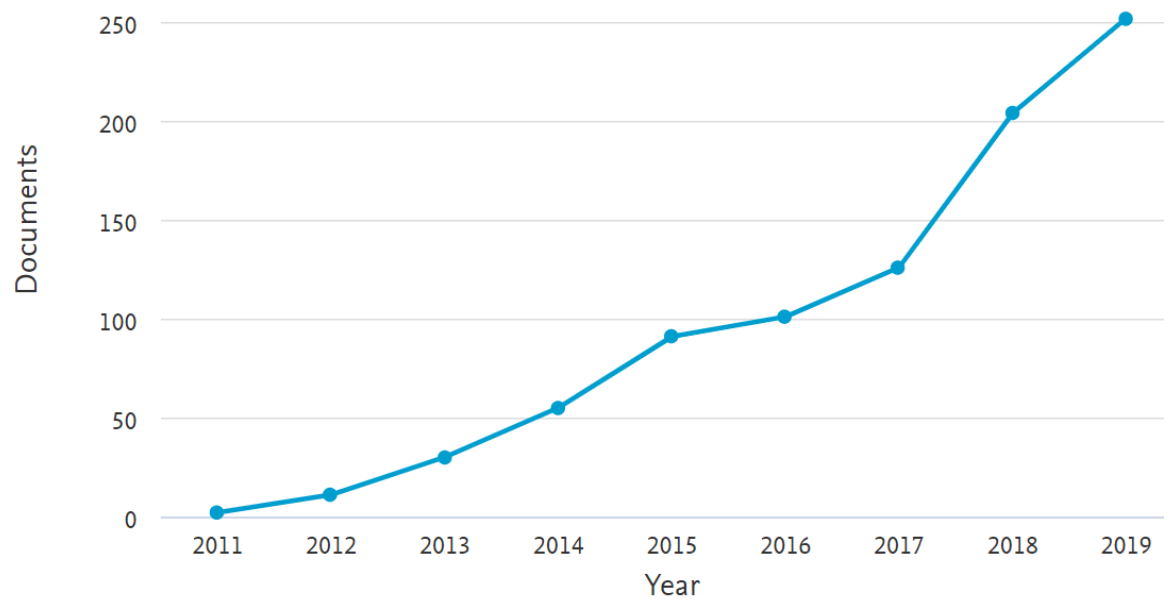

Fig. 1. Number of scientific publications addressing gamification at universities in 2011-2019.

Sources: Author's work with the use of analyses provided by Scopus database.

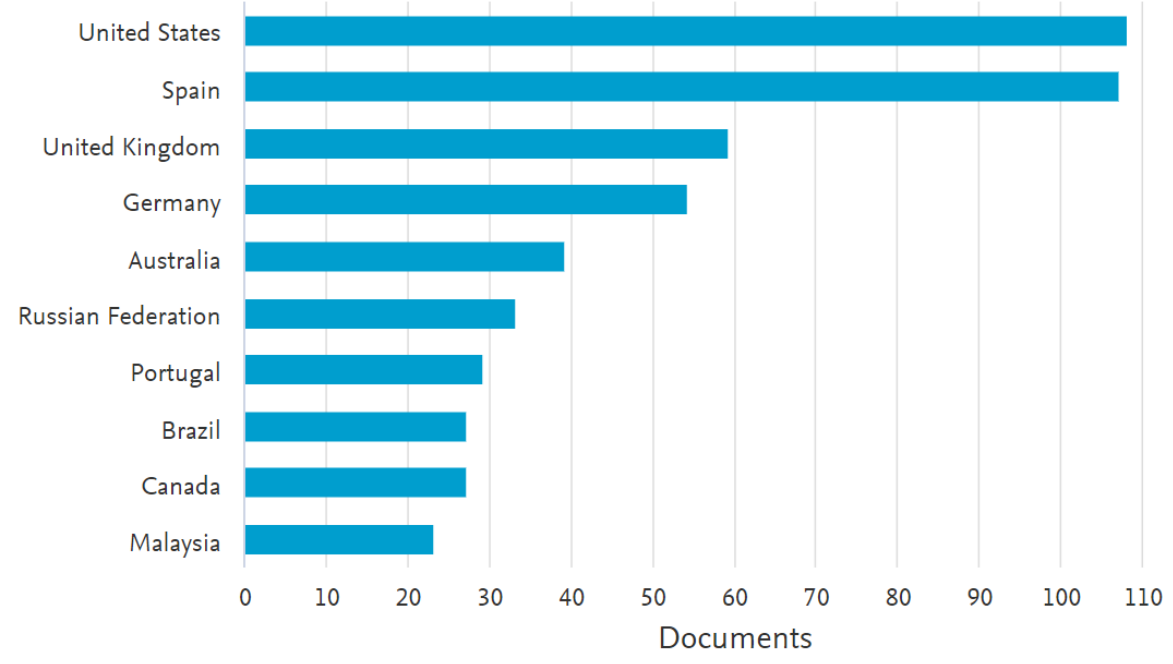

Fig. 2. Countries with the largest number of scientific publications on gamification in tertiary education.

Sources: Author's work with the use of analyses provided by Scopus database. 
Using the VosViewer software, a "density map" was generated (see Fig. 3) based on bibliographic data of the publications indexed in the Scopus database and, in particular, the co-occurrence of keywords. This map allows us to find out which issues are most often combined in scientific publications. Each point on the density map is assigned a colour indicating the keyword density at that point. By default, the colours range from blue through green to yellow. The greater the number of keywords around the point and the higher the weight of adjacent keywords, the closer the point colour to yellow. Conversely, the smaller the number of keywords around the point and the smaller their weight, the closer the point colour to blue. The main cluster, identified based on the software, indicates the coexistence of 53 keywords including, e.g., activating teaching, programme, artificial intelligence, computer, creativity, innovation, e-learning and involvement.

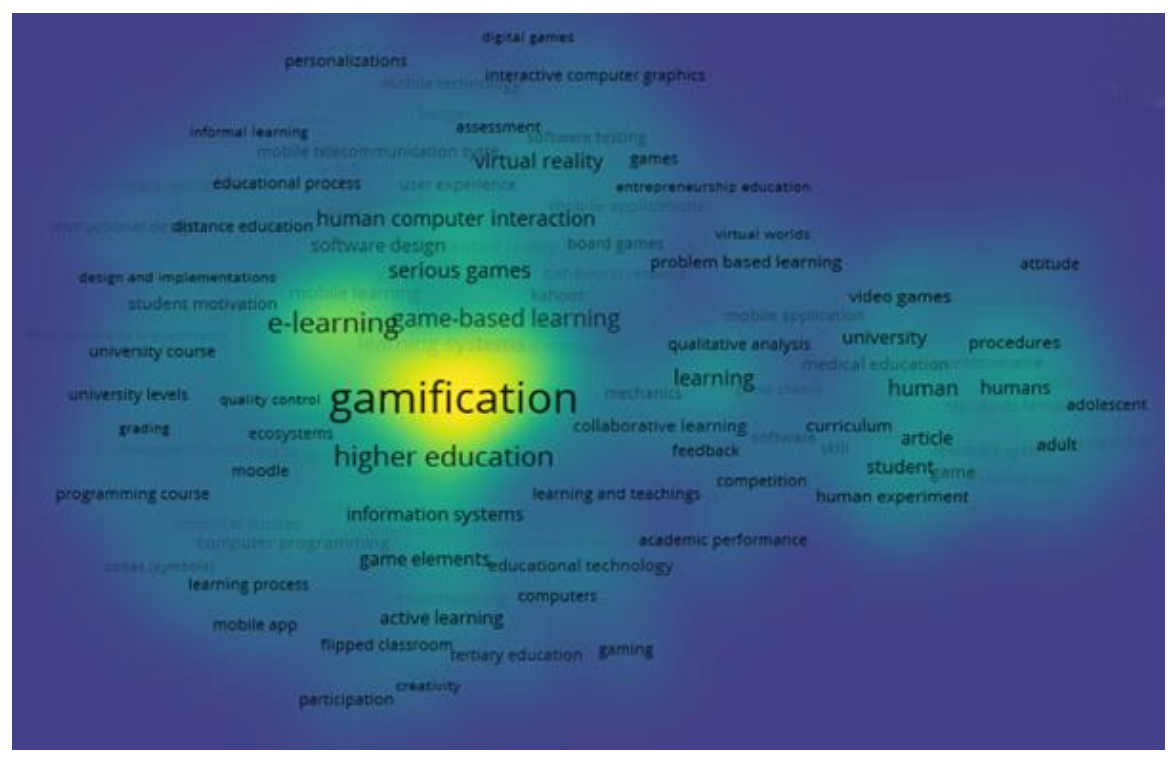

Fig. 3 The visualization of density for the publications indexed in the Scopus database.

Sources: Author's work with the use of the VosViewer software.

Although there are many publications on the use of gamification in education, empirical research of incorporating game elements in learning environments is still scarce (Dicheva et al., 2015). Therefore, it is justified to evoke 
relevant conceptual and empirical studies which focus on tertiary education. The author primarily focused on the publications that make up the H-Core of this research field according to the concept presented by Martínez, Herrera, López-Gijón, and Herrera-Viedma (2014). 30 articles presented in Appendix (Table A1) make up the H-Core (documents placed above the H-Index of the area). The purpose of this article is not to conduct a full literature review of all available publications but to illustrate how gamification is approached in tertiary education.

As far as meta-analyses (based on a systematic literature review) focused on the use of gamification in education are concerned it is worth noting that according to the results of literature studies conducted by Caponetto, Earp and Ott (2014) gamification is widely used in formal educational contexts, including university courses (43\%). In turn, literature studies carried out by Kocakoyun and Ozdamli (2018) showed that university students were the second category of the research sample frequently used in the studies related to gamification, following the category of adults. There are also meta-analyses focused not only on target group but also on the types of elements used in gamification (e.g leaderboards, badges) (Looyestyn et al., 2017) or design frameworks (Mora et al., 2017).

Subhash and Cudney (2018) carried out a systematic literature review addressing the problem of gamification in tertiary education. They identified many studies of conceptual nature. For example, Mayeret et al. (2014) created assumptions for the purposes of simulation games' evaluation. In turn, Holmes and Gee (2016) developed the classification of methods for using games in tertiary education (see Table 1).

Tab. 1. The concepts of using games in tertiary education.

\begin{tabular}{|l|l|}
\hline \multicolumn{1}{|c|}{$\begin{array}{c}\text { Original name } \\
\text { of the concept }\end{array}$} & \multicolumn{1}{c|}{ Characteristics } \\
\hline Action Frame & $\begin{array}{l}\text { The combination of gameplay and game analysis. Teachers can use games to } \\
\text { demonstrate an idea or a principle to help students experience some idea or } \\
\text { event, or even study the game as a kind of a "textual" artefact. Teachers can also } \\
\text { include games into their course content. For example, political science can study } \\
\text { various government systems using Civilization V. }\end{array}$ \\
\hline Structuring Frame & $\begin{array}{l}\text { Creating a game-based learning environment. This environment is based on } \\
\text { gamification. One of the applications of gamification is to transform science into } \\
\text { a game by adopting game elements and structures. These game elements can } \\
\text { include everything from leaderboards, merit badges or "achievements" to the } \\
\text { fully realized game narratives. }\end{array}$ \\
\hline
\end{tabular}


Tab. 1. The concepts of using games in tertiary education - cont.

\begin{tabular}{|l|l|}
\hline $\begin{array}{c}\text { Original name } \\
\text { of the concept }\end{array}$ & \multicolumn{1}{c|}{ Characteristics } \\
\hline Bridging Frame & $\begin{array}{l}\text { Connecting people. Games can be used to initiate or strengthen interpersonal } \\
\text { contacts and networking between people from various academic programmes, } \\
\text { or even educational institutions and companies. }\end{array}$ \\
\hline Designing Frame & $\begin{array}{l}\text { Changing the role of a student from a player into a game designer. Developing } \\
\text { a participatory culture. Teachers have to acquire skills related to programming } \\
\text { tools, to be able to teach students how to use these tools. }\end{array}$ \\
\hline
\end{tabular}

Sources: Author's compilation based on Holmes \& Gee, 2016.

In the tertiary education conditions, it has also been empirically proven that gamification: in general increases students' motivation (Fitz-Walter et al., 2011; Fitz-Walter et al., 2012; Hew et al., 2016), is positively perceived by students (Iosup \& Epema, 2014; Villagras et al., 2014), generates positive attitudes if students had previous experience with gamification (Fisher et al., 2013; Yildirim, 2017), when combined with social networks allows achieving better learning results than using traditional e-learning courses (Domínguez et al., 2013; De-Marcos et al., 2014; Tsay et al., 2018), increases attendance (O'Donovan et al., 2013), increases material downloads and minimizes the gap between the lowest and the top graders (Barata et al., 2013), yields better test results comparing to the groups which do not participate in gamification (Strmečki et al., 2015), supports retaining information in the long-term memory, which allows using it in the future (Pappas, 2015), positively affects students' performance through simple visualizing their behaviour, even without giving tangible rewards (Auvinen et al., 2015).

At this point, it is worth emphasizing that quantitative studies are more preferred when compared to other types of research methods (Kocakoyun \& Ozdamli, 2018). The empirical publications presented above (including all 21 empirical studies included in Appendix) were based on case studies and often used the experimental method. As Šcepanovic et al. (2015) state, the same game elements implemented in the same or similar manner but in different surroundings or courses may lead to opposing effects.

The issue of gamification is still valid. Further studies are being published and show that gamification is a useful technique supporting problem solving in terms of student involvement and motivation (Hitchens \& Tulloch, 2018). However, gamification is also subject to criticism. Dominguez et al. (2013) - the authors of most cited publication about gamification in tertiary education - found 
opinions that students prefer traditional activities because they do not think that leaderboards are a good representation of who gets more knowledge about the course. The other type of criticism is based on the statement that gamification is focused on and develops external motivation at the expense of an internal one (Banfield \& Wilkerson, 2014). In addition, some authors claim that gamification can support short-term user involvement only (Hamari et al., 2014; Hamari \& Koivisto, 2015) and even decrease intrinsic motivation (Kyewski \& Krämer, 2018). This observation brings up a certain effect of novelty. After a period of time, learners can simply get bored with this form of teaching.

\section{Research methodology}

The conducted research was a part of a larger research project dedicated to diverse teaching methods. It was carried out in three stages. The first stage covered pilot studies performed in October 2019 during lectures regarding the extent of knowledge on the concept of gamification. Since this concept was unknown to students, the second research stage addressed the method of game-based learning treated as the first step to gamification with the focus on digital games.

An auditorium survey was used in the course of the second research stage which took place in October-November 2019. Auditorium survey consists in gathering respondents within a certain space, usually in a room that is somehow related to the category being examined, and next handing out questionnaires to be completed. Unlike other survey techniques, in this case almost $100 \%$ returnability of the survey material is obtained, which affects the research reliability. The presented studies were conducted at four Wroclaw universities: Wroclaw University of Economics, University of Wroclaw, Wroclaw University of Environmental and Life Sciences and Wroclaw University of Science and Technology during the randomly selected scheduled lectures delivered by favourable teachers.

The research covered students of such fields of study as economics, humanities, natural and technical sciences (50 respondents in each group). The survey data were collected by the research team which consisted of three researchers from Wroclaw University of Economics. They explained the aim and terms used in the questionnaire to the audience.

In the course of the third research stage, in January-February 2020, a qualitative approach was used based on an in-depth interview method with the representatives of the above-mentioned universities - students (four interviews with members from each group, duration of one interview: half an hour). In this way, 
the information regarding students' experiences related to the research subject was collected. In-depth interviews take the form of face-to-face conversations aimed at obtaining more detailed information or a deep understanding of a particular subject matter (Patton, 1987).

\section{Research results}

As indicated above, the research problem addressed in various publications comes down to the mechanisms and results of applying gamification in higher education (achieved by different groups, as part of various courses, using various elements of gamification). The research purpose presented in this article is to determine the popularity of digital games compared to other teaching methods and to obtain information about the practice of using gamification in academic teaching.

The respondents were requested to specify what kind of teaching methods are most often and least often used at their universities. In addition, they were asked to arrange eight teaching methods in a sequence from 1 (the most popular method) to 8 (the least popular method). Table 1 presents the results for each student group and the summary results for all respondents. It is noticeable that lectures represent a dominating teaching method applied at universities.

The previous research, conducted outside Poland, covered the implementation of games and different mechanisms of gamification in business education (Fisher et al., 2013), medical education (Nevin et al., 2014), computer science education (Pirker et al., 2014), media studies (Hitchens \& Tulloch, 2018), primary teacher education (Cózar-Gutiérrez \& Sáez-López, 2016), engineering faculties (Iosup \& Epema, 2014; Markopoulos et al., 2015; Borras-Gene et al., 2016). However, they did not present how popular game-based learning actually is in different faculties. Table 2 shows that, in the research sample, digital games are the least frequently used teaching method in such fields of study as humanities, natural and technical sciences.

The respondents were presented with the selected competences to be developed using various teaching methods. The list of competences included, e.g.: the ability of creative thinking, interpersonal communication, assertiveness, decision-making, the ability to search for information. Digital games are recognized by the respondents as the most effective method for developing risk-taking skills regarding all groups of respondents analysed separately. Taking into account the total indications provided by all respondents $(n=200)$, it should be stated that games are considered an effective method for 
developing risk-taking skills, however, this predominance is not statistically significant as 49 respondents indicated games, whereas the second indication - a discussion was selected by 38 people. In most cases, games "lost" to the discussion method considered the most effective in the development of not just the abovementioned competences, but also, e.g., in teaching tolerance. High level of performance-avoidance orientation in the research sample can explain these research results. Performance orientation is an important factor in determining learning outcomes after implementing gamification (Hakulinen \& Auvinen, 2014).

Tab. 2. The popularity of using games comparing to other teaching methods.

\begin{tabular}{|c|c|c|c|c|c|}
\hline \multirow{2}{*}{$\begin{array}{l}\text { Teaching } \\
\text { method }\end{array}$} & \multicolumn{4}{|c|}{$\begin{array}{l}\text { Total scores by field of study } \\
\text { (the fewer points, the more popular the teaching method) }\end{array}$} & \multirow{2}{*}{ Total indications } \\
\hline & economics & humanities & natural science & $\begin{array}{l}\text { technical } \\
\text { science }\end{array}$ & \\
\hline Lecture & 52 & 86 & 62 & 74 & 274 \\
\hline Discussion & 169 & 121 & 155 & 146 & 591 \\
\hline Project method & 127 & 217 & 158 & 124 & 626 \\
\hline Case study & 184 & 244 & 221 & 229 & 878 \\
\hline Brainstorming & 239 & 202 & 274 & 216 & 931 \\
\hline Coaching & 358 & 313 & 273 & 259 & 1203 \\
\hline Role playing & 357 & 303 & 284 & 277 & 1221 \\
\hline $\begin{array}{l}\text { Digital game- } \\
\text { based learning }\end{array}$ & 309 & 314 & 356 & 321 & 1300 \\
\hline
\end{tabular}

Source: Author's research.

In-depth interviews provided information on the situations of using digital games in tertiary education. First of all, at economics courses, games are used in teaching subjects related to strategic decision making. It refers to such subjects as marketing, financial management or strategic management. Students make market decisions either individually or collectively and next receive a report presenting the results of their decisions. Frequently, games require a good command of English and describe non-existent products or currencies. For some people, participating in such a game is a big mental effort. Moreover, they do not quite comprehend why the particular, rather than different game results were achieved.

Digital quizzes are a solution well-known to students of all faculties and associated with a lot of fun. As Grünewald et al. (2013) stated, all kind of quiz- 
zes fit into a gamification system. Kahoot is the most commonly used application for this purpose according to the respondents. It confirms the analyses carried out by Kocakoyun and Ozdamli (2018) who found that mobile environments are the most frequently used ones. The test is created on https://create.kahoot.it/ website, whereas the answers are provided on https://kahoot.it/ website. Questions must be presented with the use of an overhead projector or a separate screen and the answers are entered by clicking the appropriate answer symbol on the smartphone (after entering the code in the application or on the website). After completing the quiz, the answers can be downloaded and analysed, in the case of providing answers after logging into the application students can track their own progress, which means dealing with one of the gamification elements in the form of continuous feedback on the results achieved by the user. This feedback - following an opportunity of getting extra points - is the second most effective game element in the context of increasing students' motivation (Šcepanovic et al., 2015).

The above solutions are used by younger teachers, i.e. $\mathrm{PhD}$ students and employees up to about 40 years of age. It is worth mentioning that the research carried out in Spain did not reveal any differences in using gamification by teachers' age (Martí-Parreñoa et al., 2016).

The conducted interviews show that gamification is not used as a broader concept than the previously discussed educational games. Games (traditional or digital) are included among the methods used in a classroom. Gamification - as indicated above - is a solution with a longer time perspective, a continuous one and extending beyond the university premises.

\section{Conclusions, limitations and directions for further research}

It is impossible to imagine academic classes in the 21st century without using active and modern teaching methods. They facilitate knowledge transfer in an interesting way, teach creative problem solving, arouse students' interests and allow gaining new experiences. Moreover, students' emotional involvement is also important in the course of the learning process. Hence, there is a growing interest in using gamification in academic teaching.

As the presented literature review shows, there is a lot of evidence confirming the effectiveness of using games and gamification based on them. The empirical research carried out for the purposes of this article indicates marginal application of digital games in the teaching process at various fields of study, i.e. economics, humanities, natural and technical sciences. The respondents in- 
cluded in the research sample - students of Wroclaw universities - are not familiar with the concept of gamification. In addition, certain specificity in using games was revealed. This method is applied by younger academic teachers.

Leaderboards aggregating progress of a working team and comparing it with other teams are used in the world of business. In education, gamification can be extended into more than one administrative group or university. The application of leaderboards can result in all students representing a given group/ faculty/field of study/university finding themselves on the same side. Team's overall progress can be accelerated through cooperation and mutual assistance in identifying and adopting better learning strategies. The problem of inter-university gamification has not yet been analysed. It is, therefore, an interesting challenge for both practitioners and scientists in the field of tertiary education.

The research conducted in Spain shows that teachers employed at private universities present a much more positive approach to gamification than those at public universities (Martí-Parreñoa et al., 2016). It seems worth taking up research on the approach of Polish academic teachers to using digital game-based learning and gamification (in the cross-section of age, gender and workplace).

Finally, the small size of the research sample ( 200 respondents, 50 from each university) is the limitation of the research process presented in this article. It is, therefore, worth continuing the research covering a representative sample of not only students, but also academic teachers. Moreover, a question arises whether gamification is an equally effective method in the context of different university courses. The above-presented issues can be determined by the national culture, therefore it is worth carrying out studies with the use of methods utilized in foreign countries and compare the results of similar studies. 


\section{Appendix}

Table A1. Documents indexed in the Scopus data base that make up H-Core.

\begin{tabular}{|c|c|c|c|}
\hline No. & Bibliographic data & $\begin{array}{l}\text { Type of } \\
\text { study }\end{array}$ & $\begin{array}{l}\text { Number of } \\
\text { citations } \\
\text { received }\end{array}$ \\
\hline 1. & $\begin{array}{l}\text { Domínguez, A., Saenz-De-Navarrete, J., De-Marcos, L., Fernández-Sanz, } \\
\text { L., Pagés, C., \& Martínez-Herráiz, J.-J. (2013). Gamifying Learning Expe- } \\
\text { riences: Practical Implications and Outcomes. Computers and Education, } \\
\text { 63, 380-392, doi: } 10.1016 / \text { j.compedu.2012.12.020. }\end{array}$ & empirical & 623 \\
\hline 2. & $\begin{array}{l}\text { Robson, K., Plangger, K., Kietzmann, J.H., McCarthy, I., \& Pitt, L. (2015). } \\
\text { Is it All a Game? Understanding the Principles of Gamification. Business } \\
\text { Horizons, 58(4), 411-420, doi: 10.1016/j.bushor.2015.03.006. }\end{array}$ & theoretical & 148 \\
\hline 3. & $\begin{array}{l}\text { Huotari, K., \& Hamari, J. (2016). A Definition for Gamification: Ancho- } \\
\text { ring Gamification in the Service Marketing Literature. Electronic Markets, } \\
\text { 27(1), 21-31, doi: } 10.1007 / \mathrm{s} 12525-015-0212-z \text {. }\end{array}$ & theoretical & 133 \\
\hline 4. & $\begin{array}{l}\text { losup, A., \& Epema, D. (2014). An Experience Report on Using Gami- } \\
\text { fication in Technical Higher Education. Proceedings of the } 45 \text { th ACM } \\
\text { Technical Symposium on Computer Science Education - SIGCSE '14, doi: } \\
10.1145 / 2538862.2538899 \text {. }\end{array}$ & empirical & 113 \\
\hline 5. & $\begin{array}{l}\text { O'Donovan, S., Gain, J., \& Marais, P. (2013). A Case Study in the Gamifi- } \\
\text { cation of a University-Level Games Development Course. Proceedings of } \\
\text { the South African Institute for Computer Scientists and Information Tech- } \\
\text { nologists Conference on - SAICSIT '13, doi: } 10.1145 / 2513456.2513469 .\end{array}$ & empirical & 110 \\
\hline 6. & $\begin{array}{l}\text { Fitz-Walter, Z., Tjondronegoro, D., \& Wyeth, P. (2011). Orientation Pas- } \\
\text { sport. Proceedings of the 23rd Australian Computer-Human Interaction } \\
\text { Conference on - OzCHI '11, doi: } 10.1145 / 2071536.2071554 \text {. }\end{array}$ & empirical & 95 \\
\hline 7. & $\begin{array}{l}\text { Caponetto, I., Earp, J., \& Ott, M. (2014). Gamification and Education: } \\
\text { A Literature Review. Proceedings of the European Conference on Games- } \\
\text {-based Learning, 1, 50-57. }\end{array}$ & theoretical & 85 \\
\hline 8. & $\begin{array}{l}\text { Grünewald, F., Meinel, C., Totschnig, M., \& Willems, C. (2013). Designing } \\
\text { MOOCs for the Support of Multiple Learning Styles. Scaling up Learning } \\
\text { for Sustained Impact, 371-382, doi: 10.1007/978-3-642-40814-4_29. }\end{array}$ & empirical & 72 \\
\hline 9. & $\begin{array}{l}\text { Hew, K. F., Huang, B., Chu, K.W.S., \& Chiu, D.K.W. (2016). Engaging Asian } \\
\text { Students Through Game Mechanics: Findings From Two Experiment Stu- } \\
\text { dies. Computers \& Education, 92-93, 221-236, doi: 10.1016/j.compe- } \\
\text { du.2015.10.010. }\end{array}$ & empirical & 71 \\
\hline 10. & $\begin{array}{l}\text { Nevin, C.R., Westfall, A.O., Rodriguez, J.M., Dempsey, D.M., Cherrington, } \\
\text { A., Roy, B., \& Willig, J.H. (2014). Gamification as a Tool for Enhancing } \\
\text { Graduate Medical Education. Postgraduate Medical Journal, 90(1070), } \\
685-693 \text {, doi: } 10.1136 / \text { postgradmedj-2013-132486. }\end{array}$ & empirical & 70 \\
\hline 11. & $\begin{array}{l}\text { Robson, K., Plangger, K., Kietzmann, J. H., McCarthy, I., \& Pitt, L. (2016). } \\
\text { Game on: Engaging Customers and Employees Through Gamification. Bu- } \\
\text { siness Horizons, 59(1), 29-36, doi: 10.1016/j.bushor.2015.08.002. }\end{array}$ & empirical & 64 \\
\hline 12. & $\begin{array}{l}\text { Jones, B. A., Madden, G. J., \& Wengreen, H. J. (2014). The FIT Game: } \\
\text { Preliminary Evaluation of a Gamification Approach to Increasing Fruit and } \\
\text { Vegetable Consumption in School. Preventive Medicine, 68, 76-79, doi: } \\
\text { 10.1016/j.ypmed.2014.04.015. }\end{array}$ & empirical & 60 \\
\hline
\end{tabular}


Table A1. Documents indexed in the Scopus data base that make up H-Core (cont.).

\begin{tabular}{|c|c|c|c|}
\hline No. & Bibliographic data & $\begin{array}{l}\text { Type of } \\
\text { study }\end{array}$ & $\begin{array}{l}\text { Number of } \\
\text { citations } \\
\text { received }\end{array}$ \\
\hline 13. & $\begin{array}{l}\text { Looyestyn, J., Kernot, J., Boshoff, K., Ryan, J., Edney, S., \& Maher, C. } \\
\text { (2017). Does Gamification Increase Engagement with Online Programs? } \\
\text { A Systematic Review. PLOS ONE, 12(3), e0173403, doi: 10.1371/journal. } \\
\text { pone.0173403. }\end{array}$ & theoretical & 58 \\
\hline 14. & $\begin{array}{l}\text { Yildirim, I. (2017). The Effects of Gamification-Based Teaching Practices on } \\
\text { Student Achievement and Students' Attitudes Toward Lessons. The Inter- } \\
\text { net and Higher Education, 33, 86-92, doi: 10.1016/j.iheduc.2017.02.002. }\end{array}$ & empirical & 52 \\
\hline 15. & $\begin{array}{l}\text { Sigala, M. (2015). The Application and Impact of Gamification Funwa- } \\
\text { re on Trip Planning and Experiences: The Case of TripAdvisor's Funware. } \\
\text { Electronic Markets, 25(3), 189-209, doi: 10.1007/s12525-014-0179-1. }\end{array}$ & empirical & 46 \\
\hline 16. & $\begin{array}{l}\text { Pirker, J., Riffnaller-Schiefer, M., \& Gütl, C. (2014). Motivational Active Le- } \\
\text { arning. Proceedings of the } 2014 \text { Conference on Innovation \& Technology } \\
\text { in Computer Science Education - ITiCSE '14, doi: } 10.1145 / 2591708.259 \\
1750 .\end{array}$ & empirical & 46 \\
\hline 17. & $\begin{array}{l}\text { Subhash S., \& Cudney E.A. (2018). Gamified Learning in Higher Educa- } \\
\text { tion: A Systematic Review of the Literature. Computers in Human Beha- } \\
\text { viour, 87, 192-206, doi: } 10.1016 / \text { j.chb.2018.05.028. }\end{array}$ & theoretical & 44 \\
\hline 18. & $\begin{array}{l}\text { Fotaris, P., Mastoras, T., Leinfellner, R., \& Rosunally, Y. (2016). } \\
\text { Climbing Up the Leaderboard: An Empirical Study of Applying Gamifica- } \\
\text { tion Techniques to a Computer Programming Class. Electronic Journal of } \\
\text { e-Learning, } 14 \text { (2), pp. } 94-110 .\end{array}$ & empirical & 43 \\
\hline 19. & $\begin{array}{l}\text { Hakulinen, L., Auvinen, T., \& Korhonen, A. (2015). The Effect of Achie- } \\
\text { vement Badges on Students' Behavior: An Empirical Study in a Univer- } \\
\text { sity-Level Computer Science Course. International Journal of Emerging } \\
\text { Technologies in Learning, } 10 \text { (1), 18-29, doi: 10.3991/ijet.v10i1.4221. }\end{array}$ & empirical & 41 \\
\hline 20. & $\begin{array}{l}\text { Wiggins, B.E. (2016). An Overview and Study on the Use of Games, Si- } \\
\text { mulations, and Gamification in Higher Education. International Journal } \\
\text { of Game-Based Learning, } 6(1), 18-29 \text {, doi: } 10.4018 / \text { ijgbl.2016010102. }\end{array}$ & theoretical & 37 \\
\hline 21. & $\begin{array}{l}\text { Olsson, M., Mozelius, P., Collin, J. (2015).Visualisation and Gamification of } \\
\text { E-Learning and Programming Education. Electronic Journal of e-Learning, } \\
13 \text { (6), 441-454. }\end{array}$ & empirical & 36 \\
\hline 22. & $\begin{array}{l}\text { Brigham, T.J. (2015). An Introduction to Gamification: Adding Game Ele- } \\
\text { ments for Engagement. Medical Reference Services Quarterly, } 34 \text { (4), } 471 \text { - } \\
\text { 480, doi: } 10.1080 / 02763869.2015 .1082385 \text {. }\end{array}$ & theoretical & 35 \\
\hline 23. & $\begin{array}{l}\text { Kyewski, E., \& Krämer, N.C. (2018). To Gamify or Not to Gamify? An Expe- } \\
\text { rimental Field Study of the Influence of Badges on Motivation, Activity, } \\
\text { and Performance in an Online Learning Course. Computers \& Education, } \\
118,25-37 \text {, doi: } 10.1016 / j . c o m p e d u .2017 .11 .006 .\end{array}$ & empirical & 34 \\
\hline 24. & $\begin{array}{l}\text { Mora, A., Riera, D., González, C., \& Arnedo-Moreno, J. (2017). Gamifica- } \\
\text { tion: a Systematic Review of Design Frameworks. Journal of Computing } \\
\text { in Higher Education, 29(3), 516-548, doi: } 10.1007 / 512528-017-9150-4 \text {. }\end{array}$ & theoretical & 33 \\
\hline
\end{tabular}


Table A1. Documents indexed in the Scopus data base that make up H-Core (cont.).

\begin{tabular}{|c|l|c|c|}
\hline No. & \multicolumn{1}{|c|}{ Bibliographic data } & $\begin{array}{c}\text { Type of } \\
\text { study }\end{array}$ & $\begin{array}{c}\text { Number of } \\
\text { citations } \\
\text { received }\end{array}$ \\
\hline 25. & $\begin{array}{l}\text { Borras-Gene, O., Martiñez-nunez, M., \& Fidalgo-Blanco, A. (2016). New } \\
\text { Challenges for the Motivation and Learning in Engineering Education } \\
\text { Using Gamification in M00C. International Journal of Engineering Edu- } \\
\text { cation, 32 (1), 501-512. }\end{array}$ & empirical \\
\hline 26. & $\begin{array}{l}\text { Cózar-Gutiérrez, R., \& Sáez-López, J. M. (2016). Game-Based Learning and } \\
\text { Gamification in Initial Teacher Training in the Social Sciences: An Experi- } \\
\text { ment with MinecraftEdu. International Journal of Educational Technology } \\
\text { in Higher Education, 13(1), doi: 10.1186/s41239-016-0003-4. }\end{array}$ & empirical \\
\hline 27. & $\begin{array}{l}\text { Fitz-Walter, Z., Tjondronegoro, D., \& Wyeth, P. (2012). A Gamified Mobile } \\
\text { Application for Engaging New Students At University Orientation. Proce- } \\
\text { edings of the 24th Australian Computer-Human Interaction Conference } \\
\text { on- OzCHI '12, doi: 10.1145/2414536.2414560. }\end{array}$ & 32 \\
\hline 28. empirical & $\begin{array}{l}\text { Tsay, C. H.-H., Kofinas, A., \& Luo, J. (2018). Enhancing Student Lear- } \\
\text { ning Experience With Technology-Mediated Gamification: An Empiri- } \\
\text { cal Study. Computers \& Education, 121, 1-17, doi: 10.1016/j.compe- } \\
\text { du.2018.01.009. }\end{array}$ & 32 \\
\hline 29. empirical & $\begin{array}{l}\text { Shakhovska, N., Vysotska, V., \& Chyrun, L. (2016). Features of E-Learning } \\
\text { Realization Using Virtual Research Laboratory. 2016 XIth International } \\
\text { Scientific and Technical Conference Computer Sciences and Information } \\
\text { Technologies (CSIT), doi: 10.1109/stc-csit.2016.7589891. }\end{array}$ & theoretical \\
\hline 30. & $\begin{array}{l}\text { Auvinen, T., Hakulinen, L., \& Malmi, L. (2015). Increasing Students' Awa- } \\
\text { reness of Their Behavior in Online Learning Environments with Visualiza- } \\
\text { tions and Achievement Badges. IEEE Transactions on Learning Technolo- } \\
\text { gies, 8(3), 261-273, doi: 10.1109/tlt.2015.2441718. }\end{array}$ & 31 \\
\hline
\end{tabular}

Source: Author's work with the use of bibliometric data from Scopus database.

\section{References}

Abt, C.C. (1970). Serious Games: The Art and Science of Games That Simulate Life. New York: Viking Press.

Balcerak, A., \& Woźniak, J. (2016). Gry menedżerskie. Przewodnik dla trenerów [Management Games. A Guide for Trainers]. Sopot: Gdańskie Wydawnictwo Psychologiczne.

Banfield, J., \& Wilkerson, B. (2014), Increasing Student Intrinsic Motivation and Self-Efficacy through Gamification Pedagogy. Contemporary Issues In Education Research, 7, 291-298, doi: 10.19030/cier.v7i4.8843.

Barata, G., Gama, S., Jorge, J., \& Gonçalves, D. (2013). Improving Participation and Learning with Gamification. In: L. Nacke, K. Harrigan, \& N. Randall (Eds.), Proceedings Of International Conference On Gameful Design, Research, And Applications (pp. 1017). Stratford, Canada: ACM, doi: 10.1145/2583008. 
Bellotti, F., Berta, R., De Gloria, A., Lavagnino, E., Antonaci, A., Dagnino, F. M., \& Ott, M. (2013). A Gamified Short Course for Promoting Entrepreneurship among Ict Engineering Students. In: IEEE 13th International Conference on Advanced Learning Technologies (ICALT), 1, 31-32, doi: 10.1109/ICALT.2013.14.

Brigham, T.J. (2015). An Introduction to Gamification: Adding Game Elements for Engagement. Medical Reference Services Quarterly, 34(4), 471-480, doi: 10.1080/02763869.2015.1082385.

Borras-Gene, O., Martiñez-Nunez, M., \& Fidalgo-Blanco, A. (2016). New Challenges for the Motivation and Learning in Engineering Education Using Gamification in Mooc. International Journal of Engineering Education, 32 (1), 501-512.

Caponetto, I., Earp, J., \& Ott, M. (2014). Gamification and Education: A Literature Review. Proceedings of the European Conference On Games-Based Learning, 1, 50-57.

Chorab, M. (2016). Funkcjonowanie studentów we współczesnej rzeczywistości uniwersyteckiej [Students and Their Behaviour in the Current University Reality]. Pedagogika Szkoły Wyższej, 2, 127-142, doi: 10.18276/psw.2016.2-10.

Cózar-Gutiérrez, R., \& Sáez-López, J. M. (2016). Game-Based Learning and Gamification in Initial Teacher Training in the Social Sciences: An Experiment with Minecraftedu. International Journal of Educational Technology in Higher Education, 13(1), doi: 10.1186/s41239-016-0003-4.

Decker, A., \& Lawley, E. (2013). Life's A Game and The Game of Life. In: Proceeding of the 44th ACM Technical Symposium On Computer Science Education in Denver. Denver: ACM Press, 233-238, doi: 10.1145/24451969.

De-Marcos, L., Domínguez, A., Saenz-de-Navarrete, J., \& Pagés, C. (2014). An Empirical Study Comparing Gamification and Social Networking on E-Learning. Computers \& Education, 75, 82-91, doi: 10.1016/j.compedu.2014.01.012.

Dicheva, D., Dichev, C., Agre, G., \& Angelova, G. (2015). Gamification in Education: A Systematic Mapping Study. Educational Technology \& Society, 18(3), 75-88.

Dias, J. (2017). Teaching Operations Research to Undergraduate Management Students: The Role of Gamification. The International Journal of Management Education, 15, 98-111, doi: 10.1016/j.ijme.2017.01.002.

Doliński, D. (1998), Ciemna strona rywalizacji [Dark Side of Rivalry]. Przegląd Psychologiczny, 41, 181-200.

Domínguez, A., Saenz-De-Navarrete, J., De-Marcos, L., Fernández-Sanz, L., Pagés, C., \& Martínez-Herráiz, J.-J. (2013). Gamifying Learning Experiences: Practical Implica- 
tions and Outcomes. Computers and Education, 63, 380-392, doi: 10.1016/j.compedu.2012.12.020.

Duggan, K., \& Shoup, K. (2013). Business Gamification for Dummies. New Jersey: John Willey \& Sons.

Eurostat (2020a). Students Enrolled in Tertiary Education by Education Level, Programme Orientation, Sex and Age [educ_uoe_enrt02]. Retrieved 7 Mai 2020 from https:// appsso.eurostat.ec.europa.eu/nui/submitViewTableAction.do. Eurostat (2020b). Individuals' Level Of Digital Skills [isoc_sk_dskl_i]. Retrieved 12 March 2020 from https:// ec.europa.eu/eurostat/data/databas.

Fisher, D.J., Beedle, J., \& Rouse, S.E. (2013). Gamification: A Study of Business Teacher Educators' Knowledge of, Attitudes Toward, and Experiences With the Gamification of Activities in the Classroom. The Journal of Research in Business Education, 56(1), $1-16$.

Fitz-Walter, Z., Tjondronegoro, D., \& Wyeth, P. (2011). Orientation Passport. Proceedings of the 23rd Australian Computer-Human Interaction Conference On - OzCHI '11, doi: $10.1145 / 2071536.2071554$.

Fitz-Walter, Z., Tjondronegoro, D., \& Wyeth, P. (2012). A Gamified Mobile Application for Engaging New Students at University Orientation. Proceedings of the 24th Australian Computer-Human Interaction Conference on - OzCHI '12, doi: $10.1145 / 2414536.2414560$.

Grünewald, F., Meinel, C., Totschnig, M., \& Willems, C. (2013). Designing Moocs for the Support of Multiple Learning Styles. Scaling Up Learning for Sustained Impact, 371-382, doi: 10.1007/978-3-642-40814-4_29.

Hakulinen, L., \& Auvinen, T. (2014). The Effect of Gamification on Students with Different Achievement Goal Orientations. In: B. Aris, \& A. Selamat (Eds.), Proceedings of Conference on Learning and Teaching in Computing and Engineering (LaTiCE 2014) (pp. 47-54), doi: 10.1109/LaTiCE.2014.10.

Hamari, J., Koivisto, J., \& Sarsa, H. (2014). Does Gamification Work? - A Literature Review of Empirical Studies on Gamification. Proceedings of the 47th Hawaii International Conference on System Sciences. Hawaii, USA, January 6, 1-10, doi: 10.5555/2584909.

Hamari, J, \& Koivisto, J. (2015). Why Do People Use Gamification Services?. International Journal of Information Management, 35, 419-431, doi: 10.1016/j.ijinfomgt.2015.04.006.

Hew, K. F., Huang, B., Chu, K. W. S., \& Chiu, D. K. W. (2016). Engaging Asian Students Through Game Mechanics: Findings from Two Experiment Studies. Computers \& Education, 92-93, 221-236, doi: 10.1016/j.compedu.2015.10.010. 
Hitchens, M., \& Tulloch, R. (2018). A Gamification Design for the Classroom. Interactive Technology and Smart Education, 15(1), 28-45, doi: 10.1108/ITSE-05-2017-0028.

Holmes, J.B., \& Gee, E.R. (2016). A Framework for Understanding Game-Based Teaching and Learning. On the Horizon, 24(1), 1-16, doi: 10.1108/OTH-11-2015-0069.

Huhn, P. (2019). Industry Revenue of "Publishing Computer Games" In Poland from 2011 to 2023 (In Milion US Dollars). Retrieved 17 Mai 2020 from https://www.statista.com/ forecasts/905531/publishing-of-computer-games-revenue-in-poland.

Huotari, K., \& Hamari, J. (2016). A Definition for Gamification: Anchoring Gamification in the Service Marketing Literature. Electronic Markets, 27(1), 21-31, doi: 10.1007/ s12525-015-0212-z.

Institute of Play (2014). History Of Games \& Learning. Retrieved 02 March 2020 from http://www.lrning.net/blogs/historyofgameslearning.

Iosup, A., \& Epema, D. (2014). An Experience Report on Using Gamification in Technical Higher Education. Proceedings of the 45th ACM Technical Symposium on Computer Science Education - SIGCSE '14, doi: 10.1145/2538862.2538899.

Klabbers J.H.G. (2006). The Magic Circle. Principles of Gaming and Simulation. Rotterdam-Taipei: Sense Publishers.

Kocakoyun, S., \& Ozdamli, F. (2018). A Review of Research on Gamification Approach in Education, Socialization - A Multidimensional Perspective, InTech, 51-72, doi: 10.5772/intechopen.74131.

Kolb, D.A. (1984). Experiential Learning: Experience as the Source of Learning and Development. NJ: Prentice-Hall.

Kyewski, E., \& Krämer, N. C. (2018). To Gamify or Not to Gamify? An Experimental Field Study of The Influence of Badges on Motivation, Activity, and Performance in an Online Learning Course. Computers \& Education, 118, 25-37, doi: 10.1016/j.compedu.2017.11.006.

Looyestyn, J., Kernot, J., Boshoff, K., Ryan, J., Edney, S., \& Maher, C. (2017). Does Gamification Increase Engagement with Online Programs? A Systematic Review. PLOS ONE, 12(3), e0173403, doi: 10.1371/journal.pone.0173403.

Markopoulos, A. P., Fragkou, A., Kasidiaris, P. D., \& Davim, J. P. (2015). Gamification in Engineering Education and Professional Training. International Journal Of Mechanical Engineering Education, 43(2), 118-131, doi: 10.1177/0306419015591324.

Martí-Parreñoa, J., Seguí-Masa, D., \& Seguí-Mas, E. (2016), Teachers' Attitude Towards and Actual Use of Gamification. Procedia - Social And Behavioural Sciences, 228, 682-688, doi: 10.1016/j.sbspro.2016.07.104. 
Martínez, M.A., Herrera, M., López-Gijón, J., \& Herrera-Viedma, E., (2014). H-Classics: Characterizing the Concept of Citation Classics Through H-Index. Scientometrics, 98, 1971-198, doi: 10.1007/s11192-013-1155-9.

Mayer G., Harteveld, C., Bekebrede, G., \& Warmelink, H. (2014). The Research and Evaluation of Serious Games: Toward a Comprehensive Methodology. Academy For Games \& Media, 45 (3), 502-527, doi: 10.1111/bjet.12067.

McGonigal, J. (2011). Reality Is Broken. NJ: The Penguin Press.

Misztal, A. (2015). Grywalizacja w zarządzaniu zasobami ludzkimi w przedsiębiorstwie [Gamification in Management Human Resources in Enterprise]. Nauki o Zarzadzaniu, 3(24), 91-103, doi: 10.15611/noz.2015.3.08.

Mora, A., Riera, D., González, C., \& Arnedo-Moreno, J. (2017). Gamification: A Systematic Review of Design Frameworks. Journal of Computing in Higher Education, 29(3), 516-548, doi: 10.1007/s12528-017-9150-4.

Nevin, C. R., Westfall, A. O., Rodriguez, J. M., Dempsey, D. M., Cherrington, A., Roy, B., \& Willig, J. H. (2014). Gamification as A Tool for Enhancing Graduate Medical Education. Postgraduate Medical Journal, 90(1070), 685-693, doi: 10.1136/postgradmedj-2013-132486.

O’Donovan, S., Gain, J., \& Marais, P. (2013). A Case Study in the Gamification of a University-Level Games Development Course. Proceedings of the South African Institute for Computer Scientists and Information Technologists Conference on - SAICSIT '13, doi: $10.1145 / 2513456.2513469$.

Pappas, Ch. (2015), The Top Gamification Statistics and Facts For 2015 You Need to Know. Retrieved 29 Juni 2019 from https://elearningindustry.com/top-gamification-statistics-and-facts-for-2015.

Patton, M. Q. (1987). How to Use Qualitative Methods in Evaluation. California: Sage Publications Inc.

Pirker, J., Riffnaller-Schiefer, M., \& Gütl, C. (2014). Motivational Active Learning. Proceedings of the 2014 Conference On Innovation \& Technology in Computer Science Education - ITiCSE '14, doi: 10.1145/2591708.2591750.

Reiners, T., \& Wood, L.C. (Eds.) (2014). Gamification In Education And Business. New York: Springer.

Reynol, J., \& Mastrodicasa, J. (2007). Connecting to the Net. Generation: What Higher Education Professionals Need to Know about Today's Students. Washington: National Association of Student Personnel Administrators.

Robson, K., Plangger, K., Kietzmann, J. H., McCarthy, I., \& Pitt, L. (2015). Is It All A Game? 
Understanding The Principles of Gamification. Business Horizons, 58(4), 411-420, doi: 10.1016/j.bushor.2015.03.006.

Šcepanovic, S., Žarić, N., \& Matijević, T. (2015). Gamification in Higher Education Learning - State of the Art, Challenges And Opportunities. Proceedings Of The Sixth International Conference on E-Learning (eLearning-2015), 24-25 September 2015, Belgrade, Serbia. Retrieved from https://elearningindustry.com/elearning-events/6thinternational-conference-on-e-learning-2015.

Stańczyk, P. (2007). Wykształcenie, rynek pracy i „lepsze życie” w perspektywie znaczeń nadawanych przez studentów studiów zaocznych [Education, Labour Market and "Better Life" in the Perspective of Meanings Given by Extramural Students]. Teraźniejszość- Człowiek-Edukacja, 1 (37), 41-58.

Staszel, A. (2014). Wykorzystanie grywalizacji do zwiększenia zaangażowania pracowników [Using Gamification To Increase Employee Engagement]. In: E. Piwoni-Krzeszowska, \& T Małkus (Eds.), Współczesne problemy zarządzania organizacjami [Contemporary Problems of Organization Management], (pp. 41-50). Kraków: Mfiles.

Strmečki, D., Bernik, A., \& Radošević, D. (2015). Gamification In E-Learning: Introducing Gamified Design Elements Into E-Learning Systems. Journal Of Computer Sciences, 11(12), 1108-1117, doi: 10.3844/jcssp.2015.

Subhash, S., \& Cudney, E.A. (2018). Gamified Learning in Higher Education: A Systematic Review of The Literature, Computers In Human Behaviour, 87, 192-206, doi: 10.1016/j.chb.2018.05.028.

Szuba, M. (2019a), Share of Internet Users Playing Video Games in Poland from 2014 to 2019. Retrieved 17 March 2020 from https://www.statista.com/statistics/1038861/ number-of-gamers-poland/.

Szuba, M. (2019b), Motivations to Play Video Games in Poland 2019, by Platform and Device. Retrieved 17 March 2020 from https://www.statista.com/statistics/1040964/motivations-to-play-video-games-poland/.

Tkaczyk, P. (2012). Grywalizacja. Jak zastosować mechanizm gier w działaniach marketingowych [Gamification. How to Apply Game Mechanism in Marketing]. Gliwice: Helion.

Tsay, C. H.-H., Kofinas, A., \& Luo, J. Luo, J. (2018). Enhancing Student Learning Experience With Technology-Mediated Gamification: An Empirical Study. Computers \& Education, 121, 1-17, doi: 10.1016/j.compedu.2018.01.009.

Uniwersytet.pl (2019), Techniki i metody wykorzystywane w szkoleniach [Techniques And Methods Used In Training]. Retrieved 05 January 2020 from http://www.uniwersytet. $\mathrm{pl} /$ technikiimetodywykorzystywanewszkoleniach.htm. 
Villagrasa, S., Fonseca, D., Redondo, E., \& Duran, J. (2014). Teaching Case of Gamification and Visual Technologies for Education. Journal of Cases on Information Technology, 16(4), 38-57, doi: 10.4018/jcit.2014100104.

Wiggins, B. E. (2016). An Overview and Study on the Use of Games, Simulations, and Gamification In Higher Education. International Journal of Game-Based Learning, 6(1), 18-29, doi: 10.4018/ijgbl.2016010102.

Wolf, J.P.M(Ed.) (2012) (Ed.),. Before the Crash: Early Video Game History. Detroit: Wayne State University Press.

Yildirim, I. (2017). The Effects Of Gamification-Based Teaching Practices on Student Achievement and Students' Attitudes Toward Lessons. The Internet And Higher Education, 33, 86-92, doi: 10.1016/j.iheduc.2017.02.002.

Zichermann, G., \& Cunningham, Ch. (2011). Gamification by Design. Implementing Game in Mechanics in Web and Mobile Apps. Sebastopol: O'Reilly Media. 